Ткачук Роман, E-mail: kars2004@ukr.net

ORCID iD 0000-0003-0556-7682

\title{
ПАНДЕМІЯ ЯК ЗБУРЮВАЛЬНИЙ ВПЛИВ В СИСТЕМІ УПРАВЛІННЯ ЕКСТРЕНИМ РЕАГУВАННЯМ
}

\section{https://doi.org/10.32689/2618-0065-2021-1(7)-268-302}

\begin{abstract}
Анотація. Неправочинне використання і злочинне використання небезпечних та патологічних біологічних агентів і продуктів генної інженерії та молекулярної біології може стати передумовою прояву нових інфекційних хвороб і повернення тих хвороб, що були вже подолані людством раніше. Також певну проблему становить порушення правил роботи 3 патогенними культурами і біологічних дослідницьких і промислових лабораторіях.

Сьогодення вимагає дослідження епідемій - надзвичайних ситуацій медикобіологічного характеру, як певного каталізатора подій в роботі служб екстреного реагування та перешкоди сталому функціонуванню органів управління складовими безпекових систем держави, що потребує використання іноваційних технологій прийняття управлінських рішень, що вимагають опрацювання нестандартних варіантів
\end{abstract} рішень також у сфері цивільного захисту.

За результатами аналізу нормативних актів, що $\epsilon$ підгрунтям для прийняття управлінських рішень в системі екстреного реагування на події, що є небезпечними для життя і здоров'я людей, можна засвідчити неузгодженість самих нормативних актів за рахунок незбалансованості та відсутність розуміння комплексності наслідків будьякого збурювального впливу (пандемія COVID-19) за умов незавершеної адміністративної реформи, де не відбулося чітке визначення місії, функцій і завдань центральних органів виконавчої влади, включених до складу ЄДСЦЗ.

Спираючись на аналіз подій та реакції систем управління, цивільного захисту зокрема, можна засвідчити, що такі непередбачувані, надзвичайні події, які перекручують усі розрахунки і докорінно змінюють усі існуючі уявлення, створюють не тільки додаткові перешкоди, а також створюють можливості щодо позитивних перетворень.

В межах децентралізації важливим $\epsilon$ те, що чинне законодавство наділяє органи місцевого самоврядування та місцеві органи виконавчої влади специфічними функціями та повноваженнями, зокрема щодо забезпечення санітарного та епідемічного благополуччя населення, які $є$ основою їх практичної діяльності. Крім того, що ці повноваження є специфічними (це випливає зі специфіки відповідних законів), коло повноважень місцевих державних адміністрацій та органів місцевого самоврядування $є$ досить широким. Має місце дублювання повноважень названих органів місцевої влади, що спричиняє нераціональне використання кадрових, фінансових, інших ресурсів та не сприяє підвищенню ефективності державного управління щодо забезпечення санітарного та епідемічного благополуччя населення, яке зумовлює безпеку здоров'я та життя громадян.

Ключові слова: управління, реагування, надзвичайна ситуація, пандемія, COVID-19, цивільний захист, вплив, система, органи державноъ влади та місцевого самоврядування 


\section{Науковий вісник : Державне управління №1 (7) 2021}

Постановка проблеми. Світовою кризою медичного i соціального характеру виявилася ситуація, що виникла під впливом поширення світом коронавірусної інфекції COVID-19. Цей неочікуваний, непередбачуваний збурюючий вплив («чорний лебідь») випробовує здатність політичних i економічних організацій розв'язувати проблему світового масштабу, що стосується індивідуальної взаємозалежності людей, зачіпаючи основи соціального життя.

Перший випадок коронавірусної інфекції COVID-19 в Україні було зареєстровано 03.03 .2020 р. на заході країни в Чернівецькій області. За даними Центру громадського здоров'я (ЦГЗ) MO3 України, станом на 25.03.2020 р. кількість підтверджених випадків вже досягла 113, з них чотири летальні. Ще у сотнях випадках наявної підозри на коронавірус проводилося тестування. Необхідно зауважити, що підтверджені випадки пов'язані з кількістю проведених лабораторних тестів, отже $\epsilon$ занепокоєння, що фактична кількість випадків була вищою.

Хоча наразі складно прогнозувати точну кількість людей, які постраждають унаслідок COVID-19, за оцінками різних організацій, до 50\% населення України (або майже 20 мільйонів) може бути інфіковано. 3 них до $20 \%$ випадків можуть бути складними, а 5\% критичними. Для багатьох інфекційне захворювання може протікати безсимптомно або 3 невираженими симптомами, подібно до симптомів сезонного грипу.

Всемірна організація здоров’я (далі - ВОО3) разом з Imperial College London розробляють (на момент написання статті) математичну модель оцінювання розповсюдження COVID-19 у різних умовах. Допоки не узгоджено методологію моделювання, рекомендується регулярно проводити перегляд припущень, використаних для цілей планування.

3 метою запобігання поширенню на території України гострої респіраторної хвороби COVID-19, спричиненої коронавірусом SARS-CoV-2 (далі - COVID-19), відповідно до вимог Закону України [1, ст. 26] та 3 урахуванням рішення Державної комісії з питань техногенно-екологічної безпеки та 
надзвичайних ситуацій (10.03.2020 р.) Уряд України установив 3 12 березня 2020 р. до 22 травня 2020 р. на всій території України карантин [2]. У зв'язку 3 поширенням інфекційного захворювання, пов'язаного із коронавірусом COVID-19, на всій території України було визначено низку тимчасових обмежень. Крім того, визначено класифікацію надзвичайної ситуації, що розповсюджена на всю територію України, та визначений один керівник робіт з ліквідації НС державного рівня.

У зв'язку із перманентними змінами ситуації та продовженням пандемії Урядом неодноразово приймались рішення про подовження карантину в різних його видах.

На основі внесення цих змін Литвиновським Є.Ю. виокремлено три етапи функціонування Єдиної державної системи цивільного захисту України (далі - СДСЦЗ) в умовах медико-біологічної надзвичайної ситуації природнього характеру в період з березня по жовтень 2020 року [3].

Враховуючи динаміку пандемії можна виокремити 4 етап, що розпочався внесенням чергових змін у систему реагування на надзвичайну ситуацію. Цей раз шляхом внесення змін до відповідної постанови уряду [4] рішенням [5]. Враховуючи ситуацію в світі (багато урядів країн оголошують локдаун)? може бути і 5 і 6 етапи, що будуть стосуватися різних видів обмежень соціальних контактів, аж до введення повного локдауну в Україні (при перевищенні добового приросту в 30000 осіб).

За даними Центру громадського здоров'я, станом на 10.12.2020 р. в Україні зафіксовано 13371 нових підтверджених випадків коронавірусної хвороби COVID-19 (з них дітей - 652, медпрацівників - 580). Кількість активних хворих становить 379 223 особи.

Протягом зазначеного часу під впливом пандемії та вивчення особливостей іï розвитку Міністерство охорони здоров'я (далі MO3 України) неодноразово удосконалює єдиний державний протокол лікування хворих на COVID-19. Цей протокол було розроблено фахівцями MO3 та найкваліфікованішими спеціалістами в галузі охорони здоров'я. Загалом до протоколу повністю включено підходи щодо медикаментозної терапії та 


\section{Науковий вісник : Державне управління №1 (7) 2021}

кисневої підтримки при коронавірусній інфекції у складних випадках.

Також постійно оновлюються стандарти надання медичної допомоги хворим на COVID-19, які визначають чіткий алгоритм дій при появі симптомів COVID-19. Станом на грудень 2020 року, відповідно до цих алгоритмів, пацієнтів з легкою формою захворювання, які не мають ризику ускладнень, а також пацієнтів, що одужують та вже не потребують цілодобового нагляду лікарів, рекомендовано лікувати амбулаторно, тобто в домашніх умовах.

При цьому лікарі зобов'язані забезпечити постійний контроль поточного стану пацієнта і його контактних осіб за телефоном та/або можуть здійснювати виїзні консультації 3 дотриманням правил інфекційного контролю.

Амбулаторне (домашнє) лікування суворо заборонене у разі, якщо пацієнт перебуває в групі ризику щодо розвитку ускладнень або має симптоми, що характеризують середньо-тяжкий і тяжкий перебіг. До таких симптомів відносяться: задуха; утруднене дихання; збільшення частоти дихальних рухів більше фізіологічної норми; кровохаркання; шлунково-кишкові симптоми (нудота, блювання, діарея); зміни психічного стану (сплутаність свідомості, загальмованість).

Також у всіх областях України створені мобільні бригади, які виїжджають на виклик сімейного лікаря, екстреної медичної допомоги та інших медичних працівників до пацієнтів з підозрою на COVID-19 для забору зразків на проведення досліджень у лабораторії. Це значно зменшить мобільність людей, які мають симптоми гострого вірусного захворювання та потребують здачі відповідних аналізів.

Стандарти надання медичної допомоги в Україні (COVID-19) [6], грунтуються на рекомендаціях Всесвітньої організації охорони здоров'я, оновлених після поширення хвороби за межі Китаю, та є адаптованими до потреб системи охорони здоров'я України.

Якщо система медичного захисту, на яку вперше здійснений такий удар пандемії, знаходиться в зоні уваги, то система 


\section{Науковий вісник : Державне управління №1 (7) 2021}

управління реагуванням на НС нібито знаходиться в затинку. Тому виникає необхідність простежити динаміку прийняття управлінських рішень в період функціонування СДСЦЗ в умовах реагування на конкретну НС медико-біологічного характеру, простежити взаємодію органів управління всіх рівнів при реагуванні та ії ліквідації наслідків..

Аналіз попередніх досліджень. С. Андреєв [7] дослідив генезу системи цивільного захисту в Україні. Дисертаційне дослідження цього автору було присвячено дослідженню організаційно-правового механізму державного управління цивільним захистом.

А. Рогуля дослідив питання нормативно-правового забезпечення об'єднаних територіальних громад у сфері цивільного захисту. Розглянуто досвід європейських країн в управлінні ризиками виникнення надзвичайних ситуацій за участю місцевих громад. Проаналізовано повноваження органів місцевого самоврядування (об'єднаних територіальних громад) та старости у сфері цивільного захисту. Означено основні напрями подальшої децентралізації влади у державі та передачі окремих функцій у сфері цивільного захисту органам місцевого самоврядування [8].

Н. Клименко досліджувала основні завдання єдиної державної системи цивільного захисту, іiі складові, а також режими функціонування (повсякденного функціонування; підвищеної готовності; надзвичайної ситуації; надзвичайного стану) i завдання, які система виконує у випадку їх запровадження, а також у особливий період [9].

А. Холостовою досліджено зміст та особливості становлення системи державного управління санітарно-епідеміологічним наглядом як складової суспільної безпеки в Україні. Визначено взаємозалежність рівня суспільної безпеки та рівня забезпечення належного санітарно-епідеміологічного стану в Україні. Описано складну ієрархічну трьохрівневу систему державного управління санітарно-епідеміологічним наглядом та основні напрямами діяльності Державної санітарно-епідеміологічної служби України, досліджено структуру та ї̈ особовий склад після 


\section{Науковий вісник : Державне управління №1 (7) 2021}

реструктуризації, вертикальні й інтегровані програми з охорони здоров'я, у тому числі програми профілактики захворювань через діяльність санітарно-епідеміологічних служб. Розроблено теоретичну модель, що узагальнює існуючі позитивні практики та пропозиції щодо підвищення ступеня суспільної безпеки як наслідок чіткої системи державного управління санітарноепідеміологічним наглядом та санітарної захищеності нації. Зроблено висновки на основі аналізу змісту державного управління санітарно-епідеміологічним наглядом як складової суспільної безпеки України [10].

О. Пархоменко-Куцевіл у статті [11] зроблена спроба систематизувати основні підходи до вирішення проблеми забезпечення санітарного та епідемічного благополуччя населення країни. Метою статті $\epsilon$ системний аналіз основних механізмів державного управління, спрямованих на заходи запобігання загостренню системної кризи, пов'язаної 3 виникненням і поширенням коронавірусної хвороби (COVID-19). Автором доведено, що Україна не готова до таких глобальних викликів. На сьогодні виникла об'єктивна необхідність запровадження та реалізації наступних заходів.

Н. Васюк проаналізувала сучасне нормативно-правове забезпечення повноважень місцевих державних адміністрацій та органів місцевого самоврядування щодо забезпечення санітарного та епідемічного благополуччя населення. [12]

О. Воронятніковим у статті [13] розкрито зміст державного контролю за забезпеченням санітарно-епідемічного благополуччя населення та нагляд за забезпеченням санітарно-епідемічного благополуччя населення як управлінських заходів публічного адміністрування сферою санітарного та епідемічного благополуччя населення.

Колективом авторів (С. Гур'єв, Н. Іскра, А. Терент'єва) було досліджено проблему отримання адекватної та своєчасної інформації про наслідки надзвичайної ситуації безпосередньо із зони НС для прийняття управлінських рішень. Також визначено, що частіше за все досліджувана проблема виникає 3 причини відсутності налагоджених процедур отримання та обміну 


\section{Науковий вісник : Державне управління №1 (7) 2021}

інформацією між всіма службами екстреного реагування, що залучаються до надання допомоги постраждалим в межах міжвідомчої взаємодії [15].

Однією 3 перших 3 проблематики реагування на $\mathrm{HC}$, що пов'язана 3 розповсюдженням коронавіруса? стало включене спостереження за організацією функціонування територіальної підсистеми ЄДСЦЗ в режимі НС, що проведено Є. Литвиновським [3].

Наразі, серед джерел наукової інформації наявні окремі дослідження щодо функціонування підсистеми медичного захисту СДСЦЗ при НС як складової системи цивільного захисту в різних режимах функціонування, але відсутні комплексні дослідження впливу НC медико-біологічного характеру на прийняття рішень в системі екстреного реагування на події.

Мета статті. Вивчення нормативного регулювання реагуванням органів влади та місцевого самоврядування на збурюючий вплив пандемії, що пов'язана з коронавірусом та визначення динаміки прийняття управлінських рішень в період іiі розвитку.

Виклад основного матеріалу. Наприкінці 2019 року у китайському місті Ухані зафіксували невідомий коронавірус SARS-CoV-2, який викликає потенційно смертельний розвиток пневмонії. Згодом ним були вражені понад 200 країн і територій. Всього у світі за даними Всесвітньої організації охорони здоров'я (BOO3) станом на 28 вересня 2020 року на COVID-19 захворіли понад 33 млн осіб, одужали понад 22 млн пацієнтів, померли майже 1 млн осіб. За аналогічний період в Україні зафіксовано понад 200 тисяч хворих, майже 90 тис. осіб одужали, 4 тисячі померли. Серед європейських країн найбільш уразливими виявилися Іспанія та Італія. Уряди багатьох країн змушені були ввести жорсткі заходи, що обмежують фізичне спілкування людей - локдауни та карантини, для того щоб перервати інфекційний ланцюг.

Відповідно до офіційної інформації ДСНС України за останні 15 років в Україні зареєстровано більш як 5,8 тис. класифікованих НС, в яких постраждало понад 34,1 тис. осіб, 3 


\section{Науковий вісник : Державне управління №1 (7) 2021}

них понад 6,7 тис. осіб загинуло, а прямі матеріальні збитки становлять більш ніж 30 млрд гривень. Тому зрозумілим $є$ те, що $\mathrm{HC}$, що пов'язана із розповсюдженням коронавіруса (за iii розвитком і наслідками), перевершує весь накопичений досвід реагування на НC i в рази перевищує рівень розвитку їх непередбачуваності.

Системі управління у сфері цивільного захисту притаманні всі ознаки будь-якої відкритої системи управління, яка $\epsilon$ чутливою до впливів зовнішніх чинників, якими $є$ неузгодженість нормативної бази у сфері цивільного захисту та надмірна ускладненість процедури опрацювання управлінських рішень. Системі управління цивільним захистом також притаманне прагнення зберегти стабільний стан за умови стрибкоподібного переходу 3 одного до іншого режиму функціонування при реагуванні на виникнення НС. Також невирішеним питанням, як виявилось, $\epsilon$ розмитість повноважень (про що мова піде в подальшому) між різними органами управління, як галузевими так і місцевими, а також відсутність органу взаємодії між ними у вигляді ситуаційного центру, може і постійно діючого.

Зважаючи на специфіку функціонування органів управління системою цивільного захисту, виникає потреба щодо чіткого вибору необхідних методів, методик, технологій, етапів (кроків) опрацювання управлінського рішення в умовах швидкоплинного зміну обстановки в зоні НС та впливу зовнішніх несприятливих (збурювальних) факторів тощо.

Для дослідження проблеми, що запропонована нами, вважаємо за доцільне визначитися 3 понятійно-категорійним апаратом. При цьому розуміємо, що досліджувана проблема має мультидисциплінарний характер i стосується багатьох сфер управління та науки.

На перший погляд досліджувана проблема може бути віднесена в першу чергу до медичної сфери з огляду на небезпеку для життя і здоров'я людей. При подальшому розгляді можна додатково визначити цю проблему як збурення в системі управління екстреного реагування, що більше притаманно технічним і соціальним системам управління. 


\section{Науковий вісник : Державне управління №1 (7) 2021}

Спираючись на системний метод дослідження розглянемо базові дефініції, що будемо використовувати при розгляді матеріалу статті:

Управління - функція організованих систем (біологічних, соціальних, технічних), яка забезпечує реалізацію мети i підтримку режиму діяльності, сталість і розвиток певних структурних елементів [16, с. 722].

Система - порядок, зумовлений правильним, планомірним розташуванням та взаємним зв'язком частин чого-небудь; сукупність способів, методів, прийомів здійснення чого-небудь $[17$, c. 203].

Вплив - дія, яку певна особа чи предмет або явище виявляє стосовно іншої особи чи предмета [18, с. 751].

Вплив державно-управлінський - дія органів державної влади та управління як суб'єктів державно-управлінських відносин щодо реалізації державного управління, прийняття та здійснення державно-управлінських рішень [16, с. 122].

Збурювальний вплив (збурення) - фізичний або хімічний вплив на об'єкт регулювання, що спричиняє відхилення регульованої величини [19, с. 37].

Пандемія (грец. $\pi \alpha v \delta \eta \mu i ́ \alpha-$ всенародний, від $\pi \alpha v-$ увесь + $\delta \eta \dot{\mu o \varsigma ~ « д е м о с » ~-~ н а р о д) ~-~ ф о р м а ~ е п і д е м і ч н о г о ~ п р о ц е с у, ~ д л я ~ я к о і ̈ ~}$ характерно інтенсивне масове поширення інфекційного захворювання та охоплення ним населення всієї країни, декількох країн світу або континентів.

Важливим моментом нашого дослідження $є$ опрацювання саме терміну пандемія та умов декларування цього масштабного явища, за умови того, що у вітчизняному правовому полі цей термін не визначено.

У Кодексі цивільного захисту [20] наведено визначення дефініції «епідемія» - масове поширення інфекційної хвороби серед населення відповідної території за короткий проміжок часу. Тотожне визначення також наведено в Законі України «Про захист населення від інфекційних хвороб» [1].

За визначенням ВОО3, пандемія - це поширення нового захворювання у глобальних масштабах 3 ураженням частини 


\section{Науковий вісник : Державне управління №1 (7) 2021}

населення за відносно короткий проміжок часу [21]. Причиною пандемії $є$ поява та розповсюдження нового вірусу в умовах відсутності у більшості людей імунітету до цієї інфекції, ефективних засобів профілактики (вакцини) та протоколів лікування. Пандемічне поширення характерне переважно для інфекційних хвороб з повітряно-крапельним механізмом передачі збудників.

Пандемічного масштабу в минулому набули захворювання на чуму, холеру, грип, ВІЛ-інфекцію, а тепер - коронавірусну інфекцію COVID 19.

Пандемію, що спричинена розповсюдженням коронавірусної інфекції COVID-19 у світі, оголошено BOO3, починаючи 3 11.03.2020 [22]. ВОО3 визначила сценарії розвитку подій у країнах для COVID-19 i розробила рекомендації щодо забезпечення готовності та реагування для кожного сценарію: critical preparedness, readiness and response actions for COVID-1 (критична готовність, готовність та реакція на COVID-1). Також ВOО3 оновила настанови для клініцистів «Клінічне ведення тяжкої гострої респіраторної інфекції (SARI) за підозри на захворювання COVID-19» (Clinical management of severe acute respiratory infection when novel coronavirus $(\mathrm{nCoV})$ infection is suspected).

Право кожного громадянина на охорону здоров'я та медичну допомогу встановлено ст. 46 Конституції України. Отже і захист від пандемії населення - це пряма норма Конституції України. Держава повинна забезпечити планомірне науково обгрунтоване попередження, лікування, локалізацію та ліквідацію масових інфекційних захворювань.

Згідно чинного законодавства у сфері захисту населення від інфекційних хвороб Кабінет Міністрів України повинен розробляти і реалізовувати відповідні державні цільові програми, забезпечувати фінансування та матеріально-технічне постачання закладів охорони здоров'я, установ і закладів державної санітарно-епідеміологічної служби, підприємств, установ та організацій, залучених до проведення заходів і робіт, пов'язаних з ліквідацією епідемій, координувати проведення цих заходів i 


\section{Науковий вісник : Державне управління №1 (7) 2021}

робіт, а також вирішує інші питання у межах повноважень, визначених законом.

Спеціально уповноважений центральний орган виконавчої влади 3 питань охорони здоров'я у сфері захисту населення від інфекційних хвороб розробляє, затверджує i вводить у дію санітарно-протиепідемічні правила і норми, методи обстеження та лікування хворих, діагностики та профілактики інфекційних хвороб, інші нормативно-правові акти.

Базовим у регулюванні суспільних відносин, які виникають у сфері забезпечення санітарного та епідеміологічного благополуччя, є Закон України «Про забезпечення санітарного та епідемічного благополуччя населення» [26], який визначає відповідні права і обов'язки державних органів, підприємств, установ, організацій та громадян, встановлює порядок організації державної санітарно-епідеміологічної служби і здійснення державного санітарно-епідеміологічного нагляду в Україні.

Відповідно до цього закону санітарне та епідемічне благополуччя населення - це стан здоров'я населення та середовища життєдіяльності людини, за якого показники захворюваності перебувають на усталеному рівні для даної території, умови проживання сприятливі для населення, а параметри факторів середовища життєдіяльності знаходяться в межах, визначених санітарними нормами [26, ст. 1].

Цим Законом визначено систему державної санітарноепідеміологічної служби України. Державну санітарноепідеміологічну службу України (ст. 26) очолює керівник центрального органу виконавчої влади, що реалізує державну політику у сфері санітарного та епідемічного благополуччя населення, який за посадою є головним державним санітарним лікарем України.

Головний державний санітарний лікар України у межах своїх повноважень видає накази 3 питань діяльності державної санітарно-епідеміологічної служби України, обов'язкові до виконання усіма юридичними та фізичними особами постанови, розпорядження, висновки, приписи тощо щодо дотримання вимог санітарного законодавства, проведення санітарних заходів, 


\section{Науковий вісник : Державне управління №1 (7) 2021}

вносить пропозиції центральним і місцевим органам виконавчої влади та органам місцевого самоврядування, іншим державним органам щодо забезпечення санітарного та епідемічного благополуччя населення в Україні.

Відповідно до ст. 40 Закону [26] передбачено низку повноважень, що належать виключно головним державним санітарним лікарям та посадовим особам санітарноепідеміологічної служби, зокрема:

у разі введення в Україні чи в окремих ії місцевостях режиму надзвичайного стану головний державний санітарний лікар України вносить центральному органу виконавчої влади, що забезпечує формування державної політики у сфері охорони здоров'я, обгрунтоване подання для прийняття рішення щодо звернення до Кабінету Міністрів України з пропозицією про встановлення карантину. У поданні зазначаються: період і межі території встановлення карантину; перелік проведення необхідних профілактичних, протиепідемічних та інших заходів, які можуть бути проведені у зв'язку 3 введенням режиму надзвичайного стану і встановленням карантину, виконавці цих заходів; вичерпні тимчасові обмеження прав фізичних i юридичних осіб, додаткові обов'язки, що покладаються на них;

надавати подання про запровадження особливих умов у разі виникнення чи загрози виникнення або поширення особливо небезпечних i небезпечних інфекційних хвороб, масових неінфекційних захворювань (отруєнь), радіаційних уражень населення;

надавати подання про усунення від роботи, навчання, відвідування дошкільних закладів осіб, які є носіями збудників інфекційних захворювань, хворих на небезпечні для оточуючих інфекційні хвороби, або осіб, які були в контакті 3 такими хворими;

запроваджувати позачергові профілактичні щеплення, інші санітарні заходи в разі загрози виникнення або поширення особливо небезпечних і небезпечних інфекційних хвороб.

Однак на початок пандемії систему Державної санітарноепідеміологічної служби України було реорганізовано відповідно 
[27] шляхом створення Державної служби України з питань безпечності харчових продуктів та захисту споживачів.

Також слід зазначити, що були ліквідовані без правонаступництва всі районні, міські, районні у містах, обласні, Київська та Севастопольська міські, Кримська Республіканська санітарно епідеміологічні станції, а також Центральна санітарноепідеміологічна станція MO3 України. За статутами всі ліквідовані санепідстанції були закладами охорони здоров'я. Відтак при їх ліквідації була грубо порушена ч. 3 ст. 49 Конституції України щодо неможливості скорочення існуючої мережі таких закладів.

Все вищезазначене є грубим порушенням Конституції та законів України, створює критичні й невідворотні ризики поширення масових інфекційних та неінфекційних захворювань (iз значним зростанням смертності) серед населення України через протиправну ліквідацію законних механізмів реагування на них.

Таким чином, на початок пандемії був наявним низький потенціал профілактичних і протиепідемічних заходів, який не міг бути реалізований повною мірою із-за зазначених вище оптимізацій. Покладення завдань і функцій з реалізації державної політики в сфері санітарного та епідемічного благополуччя населення i здійснення контролю (нагляду) за дотриманням вимог санітарного законодавства 3 Держепідслужби на Держпродспоживслужбу та Державну службу з питань праці, які підпорядковані, Мінекономрозвитку, а не Міністерству охорони здоров’я України негативно вплинуло на їх організацію [28].

Крім того, негативним фактором було те, що базова спеціальність «Медико-профілактична справа» вилучена 3 переліку галузей знань і спеціальностей, за якими здійснюється підготовка здобувачів вищої освіти. Набір студентів і підготовка лікарів-гігієністів та епідеміологів, яка здійснювалась на медикопрофілактичних факультетах медичних закладів вищої освіти України, - припинені. Впродовж останніх років на медичних факультетах студенти навчаються за спеціальностями «лікарська 


\section{Науковий вісник : Державне управління №1 (7) 2021}

справа» і «педіатрія», спеціальність «медико-профілактична справа» відсутня [29].

Штатні посади лікарів-гігієністів і епідеміологів у новостворених державних структурах, на які покладені функції колишньої Держсанепідслужби - Держпродспоживслужбі, Держпраці, регіональних лабораторних центрах, а також відповідних підрозділах Збройних сил України, МВС, СБУ, Прикордонній службі, Державному управлінні справами, де структури санепідслужби збережені, але під іншими назвами, заповнені лише на $30-50 \%$ i в таких умовах не можуть поповнюватися.

А на практиці, у багатьох національних системах державного управління санітарним станом та охороною здоров'я в цілому та на міжнародному рівні застосувалися вертикальні й інтегровані програми 3 охорони здоров'я, у тому числі програми профілактики захворювань через діяльність санітарноепідеміологічних служб. Вертикальні програми або автономні, категоріальні чи самостійні, передбачали вирішення конкретної проблеми профілактики захворювань шляхом застосування конкретних заходів через спеціально призначений для цього апарат управління. Вертикальні програми цілком, або в значній мірі керуються, контролюються і виконуються спеціалізованою службою, у якій для цього використовується спеціальні працівники.

У ситуації, що склалася з коронавірусною хворобою COVID2019, надзвичайно важливим стало рішення Ради національної безпеки і оборони щодо відновлення в нашій країні санітарноепідемічної служби, а також посади і статусу Головного державного санітарного лікаря. Вважаємо, що такі заходи значно посилять протиепідемічну складову як біологічної, так i національної безпеки нашої країни в цілому.

Разом із зазначеним, у зазначеній сфері визначені повноваження i органів місцевого самоврядування. Закон України [1] захист населення від інфекційних хвороб встановлює як один із пріоритетних напрямів діяльності органів виконавчої влади (зазначено вище) та органів місцевого самоврядування i 
відокремлює повноваження місцевих органів виконавчої влади та органів місцевого самоврядування у сфері захисту населення від інфекційних хвороб.

Органи місцевого самоврядування повинні забезпечити проведення профілактичних $\mathrm{i}$ протиепідемічних заходів на територіях населених пунктів, у місцях масового відпочинку населення та рекреаційних зонах, а також робіт по ліквідації епідемій та спалахів інфекційних хвороб і вирішують питання фінансового та матеріально-технічного забезпечення цих заходів i poбiт.

Крім того, органи місцевого самоврядування здійснюють комплексні заходи, спрямовані на ліквідацію епідемій, спалахів інфекційних хвороб та їх наслідків, та забезпечують участь у боротьбі з інфекційними хворобами закладів та установ охорони здоров'я усіх форм власності, а також вирішують інші питання у межах повноважень, визначених законом.

На місцеві органи виконавчої влади та органи місцевого самоврядування покладаються організація та контроль за дотриманням встановленого на території карантину правового режиму, своєчасним і повним проведенням профілактичних i протиепідемічних заходів, а також на територіях, де встановлено карантин, цим органам надається право:

залучати підприємства, установи, організації незалежно від форм власності до виконання заходів 3 локалізації та ліквідації епідемії чи спалаху інфекційної хвороби;

залучати для тимчасового використання транспортні засоби, будівлі, споруди, обладнання, інше майно підприємств, установ, організацій незалежно від форм власності, необхідне для здійснення профілактичних i протиепідемічних заходів, iз наступним повним відшкодуванням у встановленому законом порядку його вартості або витрат, пов'язаних 3 його використанням;

установлювати особливий режим в’їзду на територію карантину та виїзду з неї громадян і транспортних засобів, а у разі необхідності - проводити санітарний огляд речей, багажу, транспортних засобів та вантажів; 


\section{Науковий вісник : Державне управління №1 (7) 2021}

запроваджувати більш жорсткі, ніж встановлені нормативноправовими актами, вимоги щодо якості, умов виробництва, виготовлення та реалізації продуктів харчування, режиму обробки та якості питної води;

установлювати особливий порядок проведення профілактичних і протиепідемічних, у тому числі дезінфекційних та інших заходів;

створювати на в’їзах i виїздах із території карантину контрольно-пропускні пункти, залучати в установленому порядку для роботи в цих пунктах військовослужбовців, працівників, матеріально-технічні та транспортні засоби підприємств, установ, організацій незалежно від форм власності, частин та підрозділів спеціально уповноважених центральних органів виконавчої влади 3 питань оборони, внутрішніх справ.

У разі встановлення карантину місцеві органи виконавчої влади, органи місцевого самоврядування створюють на території карантину спеціалізовані заклади охорони здоров'я з особливим протиепідемічним режимом - спеціалізовані лікарні, ізолятори, обсерватори, використовуючи для цього приміщення закладів охорони здоров'я, оздоровчих, навчальних закладів тощо.

Визначені повноваження місцевих державних адміністрацій у сфері, що вивчається надає їм можливість вживати заходів щодо запобігання інфекційним захворюванням, епідеміям, епізоотіям та їх ліквідації та здійснювати заходи, пов'язані з мобілізаційною підготовкою, цивільним захистом на відповідній території [31, п. 5 ст. 22 , п. 2 ст. 27$]$.

Однак, як показала практика окрім нормативного визначення, засобів і сил, розгорнутих систем реагування, у тому числі і лабораторій на місцях на початок пандемії не було. Як не було i чіткою системи взаємодії органів різних рівнів [3].

Зрушенням в нормативному та організаційному забезпеченні для організації такої взаємодії, що не дозволить повторювати помилки в майбутньому $є$ схвалення Стратегії забезпечення біологічної безпеки та біологічного захисту за принципом “єдине здоров'я" на період до 2025 року та затверджено план заходів щодо іï реалізації [30]. Згідно із стратегією розв'язання проблеми 


\section{Науковий вісник : Державне управління №1 (7) 2021}

забезпечення належного рівня біологічної безпеки та біологічного захисту в Україні потребує міжсекторального співробітництва та поетапного створення єдиної системи біологічної безпеки та біологічного захисту за принципом “єдине здоров'я" і неможливе без залучення значних інтелектуальних $\mathrm{i}$ фінансових ресурсів, впровадження ефективних управлінських рішень і підтримки з боку держави, територіальних громад та міжнародної спільноти.

Відповідно до Угоди про асоціацію між Україною, з однієї сторони, та Свропейським Союзом, Європейським співтовариством з атомної енергії і їхніми державами-членами, 3 іншої сторони, Україна взяла на себе зобов'язання щодо охорони життя і здоров'я людей та тварин, запобігання поширенню на територію держави небезпечних інфекційних захворювань, вчасного реагування на спалахи небезпечних інфекційних хвороб.

Виникнення нових, повернення старих нозологічних форм небезпечних інфекційних хвороб, крім природних процесів, може бути спричинено цілеспрямованим впливом та протиправним використанням небезпечних біологічних агентів i продуктів синтетичної біології, відсутністю чітких правил під час роботи 3 небезпечними біологічними агентами.

Планом заходів щодо реалізації зазначеної Стратегії передбачалося, що протягом 2019-2020 рр. спільними зусиллями MO3 України, ДСНС України та інших заінтересованих центральних органів виконавчої влади буде розроблено та затверджено порядок взаємодії, координації та оперативного реагування заінтересованих центральних та місцевих органів виконавчої влади у разі виникнення надзвичайних ситуацій, пов'язаних 3 біологічними патогенними агентами, а також 3 метою здійснення заходів із забезпечення біологічної безпеки та біологічного захисту у сфері охорони здоров'я. Також було визначено завдання щодо забезпечення посилення кадрового потенціалу та підвищення професійного рівня фахівців шляхом проведення спеціалізованої підготовки 3 питань біологічної безпеки та біологічного захисту фахівців МВС, СБУ, 


\section{Науковий вісник : Державне управління №1 (7) 2021}

Національної гвардії, Держприкордонслужби, ДМС, ДСНС. Також у період 2020-2025 pр. передбачено розроблення та затвердження порядку проведення навчань 3 питань біологічної безпеки та біологічного захисту за участі МО3, ДСНС, інших заінтересованих центральних органів виконавчої влади, місцевих держадміністрацій. Однак, реалізація зазначених заходів знаходилась на початковому рівні і не сприяла підвищенню готовності системи управління до реагування на збурюючий вплив пандемії.

Аналізу нормативного супроводу системи екстреного реагування на пандемію свідчить, що в цілому в Україні визначені повноваження відповідних органів управління. Однак законодавче забезпечення залишилось на бумазі, а реальний стан сил і засобів спеціалізованих органів управління бажав на краще.

Крім зазначеного вище, зазначені органи державного управління та місцевого самоврядування в якості територіальних та функціональних підсистем (Відповідно до п. 1 ст. 8 Кодексу цивільного захисту) входять в СДСЦЗ, на яку також покладається поряд 3 іншими завданнями здійснення заходів щодо охорони здоров'я та санітарно-епідемічного благополуччя населення.

Відповідно до п. 1 Положення [23] СДСЦЗ - це сукупність органів управління, сил і засобів центральних та місцевих органів виконавчої влади, Ради міністрів Автономної Республіки Крим, виконавчих органів рад, підприємств, установ та організацій, які забезпечують реалізацію державної політики у сфері цивільного захисту.

Відповідно до Кодексу цивільного захисту головним завданням ЄДСЦЗ є забезпечення готовності міністерств та інших центральних та місцевих органів виконавчої влади, органів місцевого самоврядування, підпорядкованих їм сил і засобів до дій, спрямованих на запобігання і реагування на надзвичайні ситуації.

Аналіз законодавчого та нормативного забезпечення 3 питань цивільного захисту свідчить, що воно базується на Кодексі цивільного захисту та нормативних актах, що регулюють 


\section{Науковий вісник : Державне управління №1 (7) 2021}

повноваження органів державного управління та місцевого самоврядування.

Згідно з чинним законодавством України, базовими принципами $\epsilon$ :

гарантування державою громадянам конституційного права на захист життя, здоров'я та їхнього майна, а юридичним особам - права на безпечне функціонування;

добровільне залучення людей до здійснення заходів у сфері цивільного захисту, пов'язаних 3 ризиком для їхнього життя та здоров'я;

комплексний підхід до вирішення завдань цивільного захисту;

створення системи раціональної превентивної безпеки 3 метою максимально можливого, економічно обгрунтованого зменшення ймовірності виникнення надзвичайних ситуацій i мінімізації їхніх наслідків;

територіальності та функціональності єдиної системи цивільного захисту;

мінімізації заподіяння шкоди довкіллю;

гласності, вільного доступу населення до інформації у сфері цивільного захисту відповідно до законодавства.

Треба зазначити, що важливим $\epsilon$ те, що законодавчонормативним унормуванням визначені повноваження органів управління територіальними та функціональними підсистемами СДСЦЗ, Визначено, що функціональними підсистемами керують відповідні міністри, територіальними - голови ОДА та міських адміністрацій м. Київ та м. Севастополь. Крім того, відповідні центральні органи виконавчої влади утворюють спеціалізовані служби цивільного захисту, у тому числі ті, що повинні були реагувати на НС, що виникла під впливом пандемії.

Територіальні підсистеми - це все те, що $є$ і може бути залучено для цивільного захисту в області і підпорядковане голові ОДА.

Органами управління відповідно до п. 10 Положення про ЄДСЦЗ є на державному рівні - Кабінет Міністрів України, міністерства і інші центральні органи виконавчої влади. 


\section{Науковий вісник : Державне управління №1 (7) 2021}

На регіональному рівні (обласному) - обласна державна адміністрація (ОДА). На місцевому рівні - районна державна адміністрація (РДА), виконкоми рад та районні підрозділи ДСНС. Сили - це всі підрозділи, служби та формування, які залучаються до виконання завдань безпосередньо на місцях.

Положенням про СДСЦЗ [23] в п. 11 окремо визначені координаційні органи - комісії ТЕБ та НС. На державному рівні Державна комісія ТЕБ та НС. На обласному - регіональна. На місцевому (місто, район, район в місті, селище) - місцева. Ці комісії діють виключно на підставі положень про них, які затверджуються відповідно до рівня Кабінетом Міністрів України та керівниками органів управління, які утворили такі комісії. На державному рівні - урядом у вигляді постанови, на обласному головою ОДА, на місцевому - керівниками виконкомів (міські і селищні голови), головами РДА.

Положення про регіональні та місцеві комісії повинні відповідати Типовому положенню відповідно до [23], де зазначено що повноваження комісій не можуть виходити за межі Типового положення.

Одним з основних завдань регіональної комісії ТЕБ та НС відповідно до пп. 1 п. 3 є Типового положення [24] є координація діяльності райдержадміністрацій, органів місцевого самоврядування, підприємств, установ та організацій, пов'язаної iз функціонуванням територіальної підсистеми єдиної системи цивільного захисту.

У чинному законодавстві у сфері цивільного захисту не передбачено пряме вертикальне підпорядкування між собою комісій ТЕБ та НС різних рівнів, що мабуть було негативним фактором при реагуванні на зазначену НС. Тобто міська не підпорядкована обласній, а обласна не підпорядкована державній. Але комісія нижчого рівня поряд із Конституцією та законами керується і рішеннями комісії вищого рівня.

Відповідно до [25], Державна комісія 3 питань техногенноекологічної безпеки та надзвичайних ситуацій (далі - Державна комісія) $є$ постійно діючим органом, який забезпечує координацію діяльності центральних i місцевих органів 


\section{Науковий вісник : Державне управління №1 (7) 2021}

виконавчої влади, пов'язаної із забезпеченням техногенноекологічної безпеки, захисту населення і територій від наслідків НC, організаційних заходів протидії терористичній діяльності та воєнній загрозі, запобігання виникненню НС і реагування на них.

Основними завданнями, зокрема, $\epsilon$ координація діяльності центральних і місцевих органів виконавчої влади, пов'язаної із організацією і здійсненням радіаційного, хімічного, біологічного, інженерного та медичного захисту населення i територій від наслідків НС.

Проведений аналіз нормативного та організаційного забезпечення свідчить, що в Україні поряд 3 визначеною нормативно організаційною структурою, що повинна була бути готовою до реагування на НС медико-біологічного характеру, проводились перманетні зміни їх оптимізації, що не сприяли ефективності їх застосування. В даній ситуації розвиток пандемії став «чорним лебедем» для системи управління, іiі збурюючий вплив змусив систему управління швидко пристосовуватися до динаміки розвитку НС. Органи управління на першому етапі методом спроб і помилок приймали, швидкі, але незавжди адекватні рішення, деякі із яких порушували норми законодавства. Що також дає можливість припустити про недосконалість деяких його положень.

Простежимо динаміку прийняття рішень щодо мінімізації наслідків НС та реагування на зміну обстановки.

12.03.2020 на всій території України вводиться карантин та визначається низка тимчасових обмежень [1, п. 1].

Зазначимо, що обмежувати конституційні права громадян Кабінет Міністрів України не мав відповідних повноважень. Зокрема, право на пересування необхідно було обмежити законом, шляхом введення режиму надзвичайного стану.

Далі своїми розпорядженнями Кабінет Міністрів України встановив режим надзвичайної ситуації для територіальних підсистем ЄДСЦЗ [4, 5 32, 33, 34]:

16.03.2020 - Житомирської та Чернівецької областей;

18.03.2020 - Київської області; 
20.03.2020 - Івано-Франківської, Дніпропетровської областей та міста Києва;

23.03.2020. - Донецької, Тернопільської та Черкаської областей.

Тобто в даних регіонах було введено режим НС регіонального рівня, пов'язану з поширенням захворюваності на коронавірус.

На початок реагування на надзвичайну ситуацію незрозумілим було те, чому керівники адміністрацій зазначених вище регіонів звертались до Кабінету Міністрів України, коли самі володіли повноваженнями щодо реагування на $\mathrm{HC}$ відповідно до абз. 3 пп. 3 п. 23 Положення про ЄДСЦЗ [23].

25.03 .2020 p. у зв'язку із поширенням коронавірусної інфекції на всій території України Кабінет Міністрів України установив для ЄДСЦЗ режим надзвичайної ситуації, тобто всі територіальні і функціональні підсистеми переведено у режим НС [35]. У тому числі і з територіальними підсистемами тих регіонів, де до цього були оголошені НС регіонального рівня.

Режим НС подовжувався - спочатку до 24.04.2020 р., а потім тричі: до 11.05.2020 травня, до 22.05.2020 р. та до 22.06.2020 р. введеням в дію відповідних Постанов Уряду [32, 36, 37].

Отже, з 25.03.2020 в Україні введено режим НС державного рівня, що пов'язана 3 коронавірусом, і призначений один керівник робіт з ліквідації НС державного рівня. 3 початку ним став заступник Міністра охорони здоров;я - головний державний санітарний лікарь України (посада відновлена на початку карантину) а 15.04.2020 - Міністр МО3.

На нашу думку, це надзвичайно важливе рішення, яке відповідає ст. 75 Кодексу цивільного захисту України. Однак, Кабінет Міністрів не створив Комісію з ліквідації НС, а визначив, що координацію заходів щодо ліквідації наслідків надзвичайної ситуації покладено на Державну комісію 3 питань техногенноекологічної безпеки та надзвичайних ситуацій. В цей час, хоча $\mathrm{i}$ був визначений єдиний керівник робіт, однак на місцях продовжували приймати рішення регіональні та місцеві комісії 3 питань техногенно-екологічної безпеки та надзвичайних 


\section{Науковий вісник : Державне управління №1 (7) 2021}

ситуацій. Це, на думку С. Данилюка після 25.03.2020 р. «... $\epsilon$ втручанням в роботу керівника робіт з ліквідації надзвичайної ситуації та порушенням закону. Наразі щодня громадяни України стикаються із ситуаціями, коли голови ОДА, РДА, виконавчих органів рад 3 посиланням на якісь протоколи засідань комісій ТЕБ та НС різних рівнів грубо порушують закони та Конституцію під приводом боротьби з коронавірус SARS-CoV-2. Очевидним $є$ незнання, чи нерозуміння керівниками різних рівнів законодавства у сфері цивільного захисту, неухильно дотримуватись якого в надзвичайній ситуації вони зобов'язані» [8].

31 серпня до 31 грудня 2020 р. дія карантину продовжено на всій території України [4, 38].

В рішенні Уряду [4] зазначено, що залежно від епідемічної ситуації в регіоні або окремих адміністративно-територіальних одиницях регіону встановлюється «зелений», «жовтий», «помаранчевий» або «червоний» рівень епідемічної небезпеки поширення COVID-19 (далі - рівень епідемічної небезпеки).

Рівень епідемічної небезпеки встановлюється за результатом оцінки епідемічних показників та визначається рішенням Державної комісії з питань техногенно-екологічної безпеки та надзвичайних ситуацій, яке розміщується на офіційному інформаційному порталі Кабінету Міністрів України (за посиланням http://covid19.gov.ua). «Жовтий», «помаранчевий» або «червоний» рівень епідемічної небезпеки встановлюється на території регіону, в якому наявне значне поширення COVID-19.

11.11.2020 - рішенням Уряду України [5] було скасовано адаптивний карантин 3 поділом на зони і введено карантин «вихідного дня» 3 додатковими обмеженнями в період з 00 годин 00 хвилин суботи до 00 годин 00 хвилин понеділка на території України з 14 листопада 2020 до 30 листопада 2020 р.

09.12.2020 - Кабінет Міністрів України під час позачергового засідання 9 грудня ухвалив рішення [39] щодо посилення карантинних обмежень в Україні 38 до 24 січня 2021 року включно. Це рішення Уряд ухвалив за результатами обговорень 3 представниками бізнесу, місцевою владою та епідеміологами. 


\section{Науковий вісник : Державне управління №1 (7) 2021}

Висновки та напрями подальших досліджень. За результатами аналізу нормативних актів, що $є$ підгрунтям для прийняття управлінських рішень в системі екстреного реагування на події, що є небезпечними для життя і здоров'я людей, можна засвідчити неузгодженість самих нормативних актів за рахунок незбалансованості та відсутність розуміння комплексності наслідків будь-якого збурювального впливу (пандемія COVID-19) за умов незавершеної адміністративної реформи, де не відбулося чітке визначення місії, функцій і завдань центральних органів виконавчої влади, включених до складу СДСЦЗ та органів місцевого самоврядування.

Пандемія COVID-19 стала таким собі «лакмусовим папірцем», що дозволив по-новому поглянути на функціонування всієї безпекової сфери країни, зокрема функціонування відповідних підсистем СДСЦЗ. Цей зовнішній вплив дозволив зайвий раз впевнитися управлінцям у необхідності розуміння взаємного зв'язку всіх складових безпекових систем, зокрема й на територіальному рівні. Підтвердив необхідній взаємоузгодження нормативних актів, що регулюють заходи у цій сфері, і потребу існування постійно діючих ситуаційних центрів реагування на НС на державному і територіальному рівнях.

Визнання пандемії як збурювального впливу в системі управління екстреним реагуванням на події, що є небезпечними для життя і здоров'я людей можна обгрунтувати тим, що подібне явище має дуальну природу: є певним каталізатором процесів налагодження взаємодії між службами екстреного реагування i удосконалення нормативного поля, що забезпечує цю взаємодію, a також $\epsilon$ індикатором, що свідчить про прорахунки в стратегічному управлінні в безпековій сфері.

Спираючись на аналіз подій та реакції систем управління, цивільного захисту зокрема, можна засвідчити, що такі непередбачувані, надзвичайні події, які перекручують усі розрахунки i докорінно змінюють усі існуючі уявлення, створюють не тільки додаткові перешкоди, а також створюють можливості щодо позитивних перетворень. 
Грунтуючись на аналізі попередніх досліджень та результатах зазначеного вище аналізу можна визначити серед низки факторів, що визначають пандемію як збурювальний вплив в системі управління цивільним захистом ті, що на нашу думку є критично важливими, а саме: недосконала нормативно-правова база у сфері цивільного захисту (відсутність положення про підсистему біологічного захисту із визначенням сил і засобів щодо реалізації завдань цієї складової ЄДСЦЗ з метою забезпечення біологічного захисту), відсутність розуміння про комплексність наслідків НС будь-якого характеру (наявність різноманітних підходів та окремих нормативних актів, що регулюють взаємодію окремих центральних органів виконавчої влади, та проблеми щодо налагодження взаємодії 3 місцевою владою в умовах децентралізації); зниження наукового і виробничого потенціалу у медико-біологічній сфері та низький рівень інформованості населення щодо проблеми біобезпеки; нереалізовані заходи щодо Стратегіï [30].

Одним 3 шляхів підвищення рівня спроможності системи цивільного захисту реагувати на виникнення НС, тобто активно впливати на зовнішнє середовище 3 метою компенсації збурень, $є$ створення постійно діючих ситуаційних центрів 3 міжвідомчим представництвом.

В межах децентралізації важливим $\epsilon$ те, що чинне законодавство наділяє органи місцевого самоврядування та місцеві органи виконавчої влади специфічними функціями та повноваженнями, зокрема щодо забезпечення санітарного та епідемічного благополуччя населення, які $\epsilon$ основою їх практичної діяльності. Крім того, що ці повноваження $\epsilon$ специфічними (це випливає зі специфіки відповідних законів), коло повноважень місцевих державних адміністрацій та органів місцевого самоврядування $\epsilon$ досить широким. Має місце дублювання повноважень названих органів місцевої влади, що спричиняє нераціональне використання кадрових, фінансових, інших ресурсів та не сприяє підвищенню ефективності державного управління щодо забезпечення санітарного та епідемічного благополуччя населення, яке зумовлює безпеку здоров'я та життя громадян.

Перспективи подальших розвідок у даному напрямі будуть полягати у дослідженні функціонування системи цивільного захисту в умовах реагування на пандемію. 


\section{Науковий вісник : Державне управління №1 (7) 2021}

\section{Список використаних джерел}

1. Про захист населення від інфекційних хвороб : закон України від 06.04.2000 № 1645-III // База даних “Законодавство України” / BP України. https://zakon.rada.gov.ua/laws/show/1645-14\#Text (дата звернення : 20.11.2020).

2. Про запобігання поширенню на території України коронавірусу COVID-19: постанова Кабінету Міністрів України від 11 березня 2020 № 211 // Сдиний веб-портал органів виконавчої влади України / Урядовий портал. URL: https://www.kmu.gov.ua/npas/pro-zapobigannyaposhim110320rennyu-na-teritoriyi-ukrayini-koronavirusu-covid19) (дата звернення : 20.03.2020).

3 Литвиновський С. Ю. Деякі результати спостереження за організацією функціонування територіальної підсистеми єдиної державної системи цивільного захисту. Науковий вісник : державне управління. №4(6). 2020. C. 160 - 185. URL : https://doi.org/10.32689/2618-0065-2020-4(6)-160-185 구 звернення : 30.12.2020)

4 Про встановлення карантину та запровадження посилених протиепідемічних заходів на території із значним поширенням гострої респіраторної хвороби COVID-19, спричиненої коронавірусом SARS-CoV-2: постанова від 22 липня 2020 p. № 641 // Єдиний веб-портал органів виконавчої влади України / Урядовий портал. URL : https://www.kmu.gov.ua/npas/provstanovlennya-karantinu-ta-zapr-641 (дата звернення 25.12.2020).

5 Про внесення змін до постанови Кабінету Міністрів України від 22 липня 2020 р. № 641 : постанова від 11.11.2020 № 1100 // Єдиний веб-портал органів виконавчої влади України / Урядовий портал.

URL https://zakon.rada.gov.ua/laws/show/1100-2020-\%D0\%BF\#Text (дата звернення : 21.01.2021).

6 Організація надання медичної допомоги хворим на коронавірусну хворобу (COVID-19) : наказ MO3 від 28.03.2020 № 722 (зі змінами) // Вебпортал MO3 України / MO3 України. URL : https://cutt.ly/rjSZwkg (дата звернення : 21.01.2021).

7. Андреєв С. О. Державні системи цивільного захисту: інституціональні засади та проблеми розвитку : монографія. Харків : Тім Пабліш Груп, 2017. 431 с. 
8. Бабаджанова О. Ф., Рогуля А. О. Нормативно-правове забезпечення органів місцевого самоврядування у сфері цивільного захисту. Теорія та практика державного управління. 2018. № 3 (62). С. $146-153$.

9. Клименко Н. Г. Сдина державна система цивільного захисту: складові, завдання та режими функціонування. Інвестиції: практика та досвід. 2015. № 3. С. $95-100$.

10. Холостова А. М. Становлення системи державного управління санітарно-епідеміологічним наглядом як складової суспільної безпеки в Україні. Державне управління: удосконалення та розвиток : електр. наук. фах. вид. / ХарРІДУ НАДУ при Президентові України. 2014. № 2. URL: http://nbuv.gov.ua/UJRN/Duur_2014_2_4_ (дата звернення: 22.11.2020).

11. Пархоменко-Куцевіл О. I. Державне управління у сфері забезпечення санітарного та епідемічного благополуччя населення України: теоретичні аспекти. Науковий вісник: державне управління. 2020. 2. (4). C. 272 - 278 URL : https://doi.org/10.32689/10.32689/2618-0065-2020-2(4)

12. Васюк Н. О. Правові засади повноважень місцевих державних адміністрацій та органів місцевого самоврядування щодо забезпечення санітарного та епідемічного благополуччя населення. Інвестиції: практика та досвід. 2010. № 20. С. 89 93.

13. Воронятніков О. О. Поняття та особливості державного контролю за забезпеченням санітарно-епідемічного благополуччя населення та нагляду за забезпеченням санітарно-епідемічного благополуччя населення. Наукові записки. Серія: Право. 2019. Вип. 7. С. 46 - 51.

14. Данилюк С. 3 коронавірусом треба боротися, не порушуючи Конституцію (думка фахівця). Голос. : веб-сайт. URL: http://www.golos.com.ua/article/331739 (дата звернення: 20.11.2020).

15. Гур'єв С. О., Іскра Н. I., Терент'єва А. В. Інформаційна взаємодія в умовах надзвичайних ситуацій медикобіологічного характеру. Науковий вісник: державне управління. 2020. № 4 (6). С. 68 - 92. URL : https://doi.org/10.32689/2618-0065-2020-4(6)-68-92

16. Енциклопедичний словник з державного управління / за ред. Ковбасюка Ю. В., Трощинського В. П., Сурміна Ю. П. К. : НАДУ, 2010. 820 c. 


\section{Науковий вісник : Державне управління №1 (7) 2021}

17. Словник української мови : [в 11 т.] / АН Української РСР, Інт мовознав. ім. О. О. Потебні ; редкол.: І. К. Білодід (голова) [та ін.]. К. : Наук. думка, 1970 - 1980. Т. 9 : С / ред. тому: I. С. Назарова [та ін.]. 1978.916 с.

18. Словник української мови : [в 11 т.] / [АН Української РСР, Ін-т мовознав. ім. О. О. Потебні] ; редкол.: І. К. Білодід (голова) [та ін.]. К. : Наук. думка, 1970 - 1980. Т. 1 : А-В / ред. тому: П. Й. Горецький [та ін.]. 1970. XXVII. 799 с.

19. Кунцевич В. М. Адаптивное управление: алгоритмы, системы, применение. К.: Выща шк., 1988. 64 с.

20. Кодекс цивільного захисту України : закон України від 02.10.2012 p. № 5403-VI. // База даних “Законодавство України" / ВР

URL:http://zakon1.rada.gov.ua/laws/show/5403-17(дата звернення: 24.11.2020).

21. What is a pandemic? World Health Organization : веб-сайт. URL : https://cutt.ly/uj1wU2o (дата звернення: 21.11.2020).

22. WHO Director-General's opening remarks at the media briefing on COVID-19 - 11 March 2020. World Health Organization : веб-сайт. URL: https://cutt.ly/Vj1rxUs (дата звернення: 21.11.2020).

23. Про затвердження Положення про єдину державну систему цивільного захисту : постанова Кабінету Міністрів України від 09.01.2014 № 11 // База даних “Законодавство України” / ВР України. URL: https://zakon.rada.gov.ua/laws/show/11-2014п\#n10(дата звернення: 24.11.2020).

24. Про затвердження Типового положення про регіональну та місцеву комісію з питань техногенно-екологічної безпеки i надзвичайних ситуацій : постанова Кабінету Міністрів України від 17.06.2015 № 409. // База даних “Законодавство України” / BP України. URL: https://zakon.rada.gov.ua/laws/show/4092015-п(дата звернення: 24.11.2020).

25. Про Державну комісію 3 питань техногенно-екологічної безпеки та надзвичайних ситуацій : постанова Кабінету Міністрів України від 26 січня 2015 № 18 // Сдиний веб-портал органів виконавчої влади України / Урядовий портал. URL: https://zakon.rada.gov.ua/laws/show/18-2015-\%D0\%BF\#Text (дата звернення 20.03.2020).

26. Про забезпечення санітарного та епідемічного благополуччя населення : закон України від 24.02.1994 № 4004-XII // База даних "Законодавство України" / BP України. URL: 
https://zakon.rada.gov.ua/laws/show/4004-12\#Техt(дата звернення: 24.11.2020).

27. Про оптимізацію системи центральних органів виконавчої влади : постанова Кабінету Міністрів України від 10 вересня 2014 № 442 // База даних Верховної ради України / ВР України. URL: https://zakon.rada.gov.ua/laws/show/442-2014$\% \mathrm{D} 0 \% \mathrm{BF}$ Tехt (дата звернення 20.08.2020).

28. Деякі питання Державної санітарно-епідеміологічної служби : постанова Кабінету Міністрів України від 29 березня 2017 № 348 // База даних Верховної ради України / BP України. URL: https://zakon.rada.gov.ua/laws/show/348-2017-\%D0\%BF\#Text (дата звернення 20.08.2020).

29. Про затвердження переліку галузей знань і спеціальностей, за якими здійснюється підготовка здобувачів вищої освіти : постанова Кабінету Міністрів України від 29 квітня 2015 № 266 // База даних Верховної ради України / BP України. URL: https://zakon.rada.gov.ua/laws/show/266-2015-\%D0\%BF\#Text (дата звернення 20.08.2020).

30. Про схвалення Стратегії забезпечення біологічної безпеки та біологічного захисту за принципом “єдине здоров'я” на період до 2025 року та затвердження плану заходів щодо іï реалізації : розпорядження Кабінету Міністрів України від 27 листопада 2019 № 1416-p // База даних Верховної ради України / BP України. URL: https://zakon.rada.gov.ua/laws/show/1416-2019-\%D1\%80\#Text (дата звернення 20.08.2020).

31. Про місцеві державні адміністрації : закон України від 09.04.1999 № 586 // База даних “Законодавство України” / BP України. URL: http://zakon1.rada.gov.ua/cgi-bin/laws/main.cgi?nreg=586-14(дата звернення: 25.11.2020).

32. Про встановлення карантину з метою запобігання поширенню на території України гострої респіраторної хвороби COVID-19, спричиненої коронавірусом SARS-CoV-2 : постанова Кабінету Міністрів України від 20 травня 2020 № 392 // База даних Верховної ради України / BP України. URL: https://zakon.rada.gov.ua/laws/show/392-2020-\%D0\%BF\#Text

33. Про внесення змін до деяких актів Кабінету Міністрів України : постанова Кабінету Міністрів України від 17 червня 2020 № 500 // База даних Верховної ради України / BP України. URL: https://zakon.rada.gov.ua/laws/show/500-2020-\%D0\%BF\#Text

34. Про внесення змін до деяких актів Кабінету Міністрів України : постанова Кабінету Міністрів України від 26 серпня 2020 № 760 // База даних Верховної ради України / BP України. URL: https://zakon.rada.gov.ua/laws/show/500-2020-\%D0\%BF\#Text 


\section{Науковий вісник : Державне управління №1 (7) 2021}

35. Про переведення єдиної державної системи цивільного захисту у режим надзвичайної ситуації: розпорядження Кабінету Міністрів України від 25 березня 2020 № 338-р // База даних Верховної ради України / ВР України. URL: https://zakon.rada.gov.ua/laws/show/14162019-\%D1\%80\#Text (дата звернення 20.08.2020).

36. Про внесення змін до деяких актів Кабінету Міністрів України : постанова Кабінету Міністрів України від 22 квітня 2020 № 291 // База даних Верховної ради України / BP України. URL: https://zakon.rada.gov.ua/laws/show/291-2020-\%D0\%BF\#Text

37. Про внесення змін до деяких актів Кабінету Міністрів України : постанова Кабінету Міністрів України від 4 травня 2020 № 343 // База даних Верховної ради України / BP України. URL: https://zakon.rada.gov.ua/laws/show/343-2020-\%D0\%BF\#Text

38. Про визнання такими, що втратили чинність, деяких розпоряджень Кабінету Міністрів України : розпорядження Кабінету Міністрів України від 10 червня 2020 № 663-р // База даних Верховної ради України / ВР України. URL: https://zakon.rada.gov.ua/laws/show/6632020-\%D1\%80\#Text (дата звернення 20.08.2020).

39. Про встановлення карантину та запровадження обмежувальних протиепідемічних заходів 3 метою запобігання поширенню на території України гострої респіраторної хвороби COVID-19, спричиненої коронавірусом SARS-CoV-2: постанова Кабінету Міністрів України від 9 грудня 2020 № 1236 // Єдиний урядовий портал / Кабінет міністрів України. URL : https://www.kmu.gov.ua/npas/pro-vstanovlennya-karantinu-tazaprovadzhennya-obmezhuvalnih-protiepidemichnih-zahodiv-1236091220 (дата звернення 20.12.2020).

\section{References}

1. Pro zakhyst naselennia vid infektsiinykh khvorob : zakon Ukrainy vid 06.04.2000 № 1645-III // Baza danykh "Zakonodavstvo Ukrainy" / VR Ukrainy. URL: https://zakon.rada.gov.ua/laws/show/1645-14\#Text [in Ukrainian].

2. Pro zapobihannia poshyrenniu na terytorii Ukrainy koronavirusu COVID19: postanova Kabinetu Ministriv Ukrainy vid 11 bereznia 2020 № 211 // Yedynyi veb-portal orhaniv vykonavchoi vlady Ukrainy / Uriadovyi portal. URL: https://www.kmu.gov.ua/npas/pro-zapobigannyaposhim110320rennyu-na-teritoriyi-ukrayini-koronavirusu-covid-19) [in Ukrainian].

3. Lytvynovskyi Ye. Yu. Deiaki rezultaty sposterezhennia za orhanizatsiieiu funktsionuvannia terytorialnoi pidsystemy yedynoi derzhavnoi systemy tsyvilnoho zakhystu. Naukovyi visnyk : derzhavne upravlinnia. №4(6). 2020. S. 160-185. URL : https://doi.org/10.32689/2618-0065-2020-4(6)160-185 [in Ukrainian]. 


\section{Науковий вісник : Державне управління №1 (7) 2021}

4. Pro vstanovlennia karantynu ta zaprovadzhennia posylenykh protyepidemichnykh zakhodiv na terytorii iz znachnym poshyrenniam hostroi respiratornoi khvoroby COVID-19, sprychynenoi koronavirusom SARS-CoV-2: postanova vid 22 lypnia 2020 r. № 641 // Yedynyi vebportal orhaniv vykonavchoi vlady Ukrainy / Uriadovyi portal. URL : https://www.kmu.gov.ua/npas/pro-vstanovlennya-karantinu-ta-zapr-641 [in Ukrainian].

5. Pro vnesennia zmin do postanovy Kabinetu Ministriv Ukrainy vid 22 lypnia 2020 r. № 641 : postanova vid 11.11.2020 № 1100 // Yedynyi vebportal orhaniv vykonavchoi vlady Ukrainy / Uriadovyi portal. URL : https://zakon.rada.gov.ua/laws/show/1100-2020-\%D0\%BF\#Text [in Ukrainian].

6. Orhanizatsiia nadannia medychnoi dopomohy khvorym na koronavirusnu khvorobu (COVID-19) : nakaz MOZ vid 28.03.2020 № 722 (zi zminamy) // Vebportal MOZ Ukrainy / MOZ Ukrainy. URL : https://cutt.ly/rjSZwkg ([in Ukrainian].

7. Andreiev S. O. Derzhavni systemy tsyvilnoho zakhystu: instytutsionalni zasady ta problemy rozvytku : monohrafiia. Kharkiv : Tim Pablish Hrup, 2017. 431 s. [in Ukrainian].

8. Babadzhanova O. F., Rohulia A. O. Normatyvno-pravove zabezpechennia orhaniv mistsevoho samovriaduvannia u sferi tsyvilnoho zakhystu. Teoriia ta praktyka derzhavnoho upravlinnia. 2018. № 3 (62). S. $146-$ 153.

9. Klymenko N.H. Yedyna derzhavna systema tsyvilnoho zakhystu: skladovi, zavdannia ta rezhymy funktsionuvannia. Investytsii: praktyka ta dosvid. 2015. № 3. S. 95 - 100 [in Ukrainian].

10. Kholostova A. M. Stanovlennia systemy derzhavnoho upravlinnia sanitarno-epidemiolohichnym nahliadom yak skladovoi suspilnoi bezpeky v Ukraini. Derzhavne upravlinnia: udoskonalennia ta rozvytok : elektr. nauk. fakh. vyd. / KharRIDU NADU pry Prezydentovi Ukrainy. 2014. № 2. URL: http://nbuv.gov.ua/UJRN/Duur_2014_2_4 [in Ukrainian].

11. Parkhomenko-Kutsevil O. I. Derzhavne upravlinnia u sferi zabezpechennia sanitarnoho ta epidemichnoho blahopoluchchia naselennia Ukrainy: teoretychni aspekty. Naukovyi visnyk: derzhavne upravlinnia. 2020. 2. (4). S. 272 - 278 URL : https://doi.org/10.32689/10.32689/2618-0065-2020-2(4) [in Ukrainian].

12. Vasiuk N. O. Pravovi zasady povnovazhen mistsevykh derzhavnykh administratsii ta orhaniv mistsevoho samovriaduvannia shchodo zabezpechennia sanitarnoho ta epidemichnoho blahopoluchchia naselennia. Investytsii: praktyka ta dosvid. 2010. № 20. S. 89 - 93 [in Ukrainian].

13. Voroniatnikov O. O. Poniattia ta osoblyvosti derzhavnoho kontroliu za zabezpechenniam sanitarno-epidemichnoho blahopoluchchia naselennia ta nahliadu za zabezpechenniam sanitarno-epidemichnoho 


\section{Науковий вісник : Державне управління №1 (7) 2021}

blahopoluchchia naselennia. Naukovi zapysky. Seriia: Pravo. 2019. Vyp. 7. S. $46-51$ [in Ukrainian].

14. Danyliuk S. Z koronavirusom treba borotysia, ne porushuiuchy Konstytutsiiu (dumka fakhivtsia). Holos. : veb-sait. URL: http://www.golos.com.ua/article/331739 ([in Ukrainian].

15. Huriev S. O., Iskra N. I., Terentieva A. V. Informatsiina vzaiemodiia v umovakh nadzvychainykh sytuatsii medyko-biolohichnoho kharakteru. Naukovyi visnyk: derzhavne upravlinnia. 2020. № 4 (6). S. 68 - 92. URL : https://doi.org/10.32689/2618-0065-2020-4(6)-68-92 [in Ukrainian].

16. Entsyklopedychnyi slovnyk $\mathrm{z}$ derzhavnoho upravlinnia / za red. Kovbasiuka Yu. V., Troshchynskoho V. P., Surmina Yu. P. K. : NADU, 2010. 820 s. [in Ukrainian].

17. Slovnyk ukrainskoi movy : [v 11 t.] / AN Ukrainskoi RSR, In-t movoznav. im. O. O. Potebni ; redkol.: I. K. Bilodid (holova) [ta in.]. K. : Nauk. dumka, 1970 - 1980. T. 9 : C / red. tomu: I. S. Nazarova [ta in.]. 1978. 916 c. [in Ukrainian].

18. Slovnyk ukrainskoi movy : [v 11 t.] / [AN Ukrainskoi RSR, In-t movoznav. im. O. O. Potebni] ; redkol.: I. K. Bilodid (holova) [ta in.]. K. : Nauk. dumka, 1970 - 1980. T. 1 : A-V / red. tomu: P. Y. Horetskyi [ta in.]. 1970. XXVII. 799 c. [in Ukrainian].

19. Kuntsevych V.M. Adaptyvnoe upravlenye: alhorytmы, systemы, prymenenye. K.: Vыshcha shk., 1988. 64 s. [in Ukrainian].

20. Kodeks tsyvilnoho zakhystu Ukrainy : zakon Ukrainy vid 02.10.2012 r. № 5403-VI. // Baza danykh "Zakonodavstvo Ukrainy" / VR Ukrainy. URL:http://zakon1.rada.gov.ua/laws/show/5403-17[in Ukrainian].

21. What is a pandemic? World Health Organization : veb-sait. URL : https://cutt.ly/uj1wU2o [in Ukrainian].

22. WHO Director-Generals opening remarks at the media briefing on COVID-19 - 11 March 2020. World Health Organization : veb-sait. URL: https://cutt.ly/Vj1rxUs [in Ukrainian].

23. Pro zatverdzhennia Polozhennia pro yedynu derzhavnu systemu tsyvilnoho zakhystu : postanova Kabinetu Ministriv Ukrainy vid 09.01.2014 № 11 // Baza danykh "Zakonodavstvo Ukrainy" / VR Ukrainy. URL: https://zakon.rada.gov.ua/laws/show/11-2014-p\#n10([in Ukrainian].

24. Pro zatverdzhennia Typovoho polozhennia pro rehionalnu ta mistsevu komisiiu z pytan tekhnohenno-ekolohichnoi bezpeky i nadzvychainykh sytuatsii : postanova Kabinetu Ministriv Ukrainy vid 17.06.2015 № 409. // Baza danykh "Zakonodavstvo Ukrainy" / VR Ukrainy. URL: https://zakon.rada.gov.ua/laws/show/409-2015-p [in Ukrainian].

25. Pro Derzhavnu komisiiu z pytan tekhnohenno-ekolohichnoi bezpeky ta nadzvychainykh sytuatsii : postanova Kabinetu Ministriv Ukrainy vid 26 sichnia 2015 № 18 // Yedynyi veb-portal orhaniv vykonavchoi vlady Ukrainy

$$
\text { / Uriadovyi }
$$
portal.

URL: 
https://zakon.rada.gov.ua/laws/show/18-2015-\%D0\%BF\#Text [in Ukrainian].

26. Pro zabezpechennia sanitarnoho ta epidemichnoho blahopoluchchia naselennia : zakon Ukrainy vid 24.02.1994 № 4004-XII // Baza danykh "Zakonodavstvo Ukrainy" / VR Ukrainy. URL: https://zakon.rada.gov.ua/laws/show/4004-12\#Text [in Ukrainian].

27. Pro optymizatsiiu systemy tsentralnykh orhaniv vykonavchoi vlady : postanova Kabinetu Ministriv Ukrainy vid 10 veresnia 2014 № 442 // Baza danykh Verkhovnoi rady Ukrainy / VR Ukrainy. URL: https://zakon.rada.gov.ua/laws/show/442-2014-\%D0\%BF\#Text ([in Ukrainian].

28. Deiaki pytannia Derzhavnoi sanitarno-epidemiolohichnoi sluzhby : postanova Kabinetu Ministriv Ukrainy vid 29 bereznia 2017 № 348 // Baza danykh Verkhovnoi rady Ukrainy / VR Ukrainy. URL: https://zakon.rada.gov.ua/laws/show/348-2017-\%D0\%BF\#Text [in Ukrainian].

29. Pro zatverdzhennia pereliku haluzei znan i spetsialnostei, za yakymy zdiisniuietsia pidhotovka zdobuvachiv vyshchoi osvity : postanova Kabinetu Ministriv Ukrainy vid 29 kvitnia 2015 № 266 // Baza danykh Verkhovnoi rady Ukrainy / VR Ukrainy. URL: https://zakon.rada.gov.ua/laws/show/266-2015-\%D0\%BF\#Text [in Ukrainian].

30. Pro skhvalennia Stratehii zabezpechennia biolohichnoi bezpeky ta biolohichnoho zakhystu za pryntsypom "iedyne zdorovia" na period do 2025 roku ta zatverdzhennia planu zakhodiv shchodo yii realizatsii : rozporiadzhennia Kabinetu Ministriv Ukrainy vid 27 lystopada 2019 № 1416-r // Baza danykh Verkhovnoi rady Ukrainy / VR Ukrainy. URL: https://zakon.rada.gov.ua/laws/show/1416-2019-\%D1\%80\#Text [in Ukrainian].

31. Pro mistsevi derzhavni administratsii : zakon Ukrainy vid 09.04.1999 № 586 // Baza danykh "Zakonodavstvo Ukrainy" / VR Ukrainy. URL: http://zakon1.rada.gov.ua/cgi-bin/laws/main.cgi?nreg=586-14 ([in Ukrainian].

32. Pro vstanovlennia karantynu $\mathrm{z}$ metoiu zapobihannia poshyrenniu na terytorii Ukrainy hostroi respiratornoi khvoroby COVID-19, sprychynenoi koronavirusom SARS-CoV-2 : postanova Kabinetu Ministriv Ukrainy vid 20 travnia 2020 № 392 // Baza danykh Verkhovnoi rady Ukrainy / VR Ukrainy. URL: https://zakon.rada.gov.ua/laws/show/392-2020-\%D0\%BF\#Text [in Ukrainian].

33. Pro vnesennia zmin do deiakykh aktiv Kabinetu Ministriv Ukrainy : postanova Kabinetu Ministriv Ukrainy vid 17 chervnia 2020 № 500 // Baza danykh Verkhovnoi rady Ukrainy / VR Ukrainy. URL: https://zakon.rada.gov.ua/laws/show/500-2020-\%D0\%BF\#Text

[in Ukrainian]. 


\section{Науковий вісник : Державне управління №1 (7) 2021}

34. Pro vnesennia zmin do deiakykh aktiv Kabinetu Ministriv Ukrainy : postanova Kabinetu Ministriv Ukrainy vid 26 serpnia 2020 № 760 // Baza danykh Verkhovnoi rady Ukrainy / VR Ukrainy. URL: https://zakon.rada.gov.ua/laws/show/500-2020-\%D0\%BF\#Text [in Ukrainian].

35. Pro perevedennia yedynoi derzhavnoi systemy tsyvilnoho zakhystu u rezhym nadzvychainoi sytuatsii: rozporiadzhennia Kabinetu Ministriv Ukrainy vid 25 bereznia 2020 № 338-r // Baza danykh Verkhovnoi rady Ukrainy / VR Ukrainy. URL: https://zakon.rada.gov.ua/laws/show/14162019-\%D1\%80\#Text ([in Ukrainian].

36. Pro vnesennia zmin do deiakykh aktiv Kabinetu Ministriv Ukrainy : postanova Kabinetu Ministriv Ukrainy vid 22 kvitnia 2020 № 291 // Baza danykh Verkhovnoi rady Ukrainy / VR Ukrainy. URL: https://zakon.rada.gov.ua/laws/show/291-2020-\%D0\%BF\#Text [in Ukrainian].

37. Pro vnesennia zmin do deiakykh aktiv Kabinetu Ministriv Ukrainy : postanova Kabinetu Ministriv Ukrainy vid 4 travnia 2020 № 343 // Baza danykh Verkhovnoi rady Ukrainy / VR Ukrainy. URL: https://zakon.rada.gov.ua/laws/show/343-2020-\%D0\%BF\#Text [in Ukrainian].

38. Pro vyznannia takymy, shcho vtratyly chynnist, deiakykh rozporiadzhen Kabinetu Ministriv Ukrainy : rozporiadzhennia Kabinetu Ministriv Ukrainy vid 10 chervnia 2020 № 663-r // Baza danykh Verkhovnoi rady Ukrainy / VR Ukrainy. URL: https://zakon.rada.gov.ua/laws/show/6632020-\%D1\%80\#Text (data zvernennia 20.08.2020). [in Ukrainian].

39. Pro vstanovlennia karantynu ta zaprovadzhennia obmezhuvalnykh protyepidemichnykh zakhodiv $\mathrm{z}$ metoiu zapobihannia poshyrenniu na terytorii Ukrainy hostroi respiratornoi khvoroby COVID-19, sprychynenoi koronavirusom SARS-CoV-2: postanova Kabinetu Ministriv Ukrainy vid 9 hrudnia 2020 № 1236 // Yedynyi uriadovyi portal / Kabinet ministriv Ukrainy. URL https://www.kmu.gov.ua/npas/pro-vstanovlennya-karantinu-tazaprovadzhennya-obmezhuvalnih-protiepidemichnih-zahodiv-1236091220 [in Ukrainian]. 


\section{A PANDEMIC AS A DISTURBING EFFECT IN THE EMERGENCY RESPONSE MANAGEMENT SYSTEM Tkachuk Roman}

Abstract. The emergence of new, the return of old nosological forms of dangerous infectious diseases, in addition to natural processes, can be caused by the targeted exposure and illegal use of hazardous biological agents and products of synthetic biology, the lack of clear rules when working with dangerous biological agents.

Solving the problem of ensuring an appropriate level of biological safety and biological protection in Ukraine requires intersectoral cooperation and the step-by-step creation of a single system of biological safety and biological protection according to the principle of "one health" and is impossible without the attraction of significant intellectual and financial resources, the introduction of effective management decisions and support from the state, territorial communities and the international community.

According to the results of the analysis of regulatory acts, which is the basis for making management decisions in the system of emergency response to events, are dangerous to human life and health, we can say that the most regulatory acts are inconsistent due to imbalance and a lack of understanding of the complexity of the consequences of any disturbing impact (COVID-19 pandemic) in the conditions of an unfinished administrative reform, where there was a clear definition of the mission, functions and tasks of the central executive bodies included in the United state system of civil protection.

Based on the analysis of events and the reaction of control systems, civil protection in particular, we can say that such unpredictable, emergencies that twist all calculations and radically change all existing ideas, create not only additional obstacles, but also create opportunities for positive changes.

Within the framework of decentralization, it is important that the current legislation endows local self-government bodies and local executive authorities with specific functions and powers, in particular, to ensure the sanitary and epidemic well-being of the population, which are the basis of their practice. In addition to the fact that these powers are specific (this follows from the specifics of the relevant laws), the scope of powers of local state administrations and local self-government bodies is quite wide. There is a duplication of the powers of these local authorities, which causes an irrational use of human, financial, and other resources and does not contribute to an increase in the efficiency of state administration to ensure the sanitary and epidemic well-being of the population, leads to the safety of the health and life of citizens.

Key words: management, response, emergency, pandemic, civil protection, impact, system. 